\title{
Habitat structure in soft-sediment environments and abundance of juvenile snapper Pagrus auratus
}

\author{
Simon F. Thrush ${ }^{1, *}$, Diane Schultz $^{1}$, Judi E. Hewitt ${ }^{1}$, Drew Talley ${ }^{2}$ \\ ${ }^{1}$ National Institute of Water and Atmospheric Research, PO Box 11-115, Hamilton, New Zealand \\ ${ }^{2}$ Scripps Institution of Oceanography, University of California-San Diego, La Jolla, California 92093-0201, USA
}

\begin{abstract}
Small-scale biogenic or physical features, such as depressions, burrows, shells, boulders, cobbles and sand waves, dominate soft-sediment coastal and shelf environments. Such structures may provide refuge from predation and feeding areas for juvenile fish. We investigated the potential for juvenile snapper Pagrus auratus to utilise areas characterised by small-scale structures by sampling soft-sediment habitats that varied in both sediment characteristics and biogenic structure. Juvenile snapper abundance was estimated at each site using opera house traps, while variations in small-scale benthic habitat structure were quantified from video transects of the seafloor. The captured fish had $172 \pm 43 \mathrm{~mm}$ fork length, indicating that they were 1 to $2 \mathrm{yr}$ old. Statistical modelling revealed that complex habitat structure had a positive influence on the abundance of juvenile snapper, suggesting that these areas are preferentially utilised. This finding highlights the potential for disturbance of such structures (by, for example, trawling or dredging) to affect the abundance of juvenile snapper.
\end{abstract}

KEY WORDS: Seafloor habitat · Juvenile fish · Pagrus · New Zealand · Sustainable fisheries · Sparidae

Resale or republication not permitted without written consent of the publisher

\section{INTRODUCTION}

The potential for complex seafloor habitats to influence the survivorship of juvenile life stages of exploited demersal fin-fish species has been implicitly acknowledged by the identification of nursery areas (e.g. Bradstock \& Gordon 1983). The recent legislative framework for fisheries management explicitly recognises the need to determine ecological links between exploited fish populations and their environment (e.g. in the USA the Sustainable Fisheries Act [SFA] 1996 refers to 'essential fish habitat' and in New Zealand the 1996 Fisheries Act refers to 'habitat of particular significance for fisheries management'). However, knowledge of natural history and habitat requirements for different life stages of exploited populations is often unavailable. Auster et al. (1995) have demonstrated specific habitat associations for mobile megafauna

*Email: s.thrush@niwa.cri.nz (demersal fishes and crustaceans). They observed that small-scale biogenic or physical features, such as depressions, burrows, shells, boulders cobbles and sand waves, were important elements providing structure in sedimentary habitats that dominate coastal and shelf environments. In contrast to the paucity of information on the ecology of exploited fish species, a number of ecological studies of fishes in lakes and marine reef and seagrass habitats have shown that habitat structure can play an important role in influencing juvenile survivorship (e.g. Heck \& Thoman 1981, Persson \& Eklov 1995, Rooker et al. 1998).

There is growing awareness of the need to broaden the scope of fisheries management by moving away from considering fish stocks in isolation and towards placing fish within an ecological and environmental context (e.g. Fluharty 2000). This implies that we need to develop an understanding of how a fish habitat is defined and the role that habitat structure can play in developing sustainable fisheries (Able et al. 1999). 
Describing fish-habitat relationships and understanding the underlying mechanisms is complicated by ontogenetic changes in habitat requirements and the spatial scales over which mobile individuals integrate habitats. In terrestrial ecosystems, there is a recognised relationship between spatial scales of mobility and body size (e.g. Addicot et al. 1987, Kotliar \& Wiens 1990), but in fluid environments such movement and body size scaling rules are not so clear. For most commercially exploited species, there is insufficient information to define the spatial scales of their habitat. Nevertheless, given the 3D nature of biogenic features in sedimentary habitats, and the often high levels of predation on juvenile life stages, it is likely that if biogenic habitat structure plays a role in the population dynamics of a fish species, this role will be most important for juvenile life stages. As a first step to identifying the relationship between benthic habitat and fish, we aim to determine the importance of habitat structure in influencing the abundance of juvenile snapper.

Snapper Pagrus auratus (Sparidae) is one of the most intensively studied fish species in New Zealand; it supports a valuable recreational and commercial fishery (Francis \& Williams 1995). Diver observations on the density of juvenile snapper within a small reef system have shown large differences in the density of fish over small spatial scales (10s of metres) that were broadly related to habitat (Kingett \& Choat 1981). The highest densities of Year 0+ fish (i.e. fish in their first year of life) were found on sedimentary flats adjacent to rocky reef and kelp forest, and associated with turfing coralline algae Corallina officinalis. In contrast, low densities of fish older than Year 0+ were found in the reef system (Kingett \& Choat 1981). Trawl surveys of juvenile snapper (Year $0+, 1+$ and $2+$ cohorts) have also demonstrated consistently high levels of spatial variation at the $1 \mathrm{~km}$ scale (Francis 1995). This pattern was explained as a preference by the juveniles for muddy substrates over muddy sand-shell hash substrates, although this could not be adequately tested due to insufficient spatial resolution of the trawl samples. These 2 studies emphasise the importance of shallow coastal sedimentary habitats for juvenile snapper of different ages over the summer months. However, neither of these previous studies was designed to identify relationships between the abundance of juvenile snapper and elements of habitat structure in soft-sediment environments that are susceptible to disturbance.

The present study was designed to explore whether habitat utilisation by juvenile snapper, at the $>1 \mathrm{~km}$ scale, was related to the presence of small-scale habitat features. Although seafloor habitat biogenic features (e.g. presence of sponges, hydroids, suspension feeding bivalves) as well as heterogeneity created by physical features (e.g. cobbles, shell hash, sand waves) have the potential to provide important habitat to juvenile fish, these elements are often removed by repeated fishing disturbance. These habitat features are often positively related to macrobenthic diversity (Thrush et al. 2001), and are often highly variable over small spatial scales (>1 km; e.g. Schneider et al. 1987). This heterogeneity limits the detection of ecological patterns based on traditional fish sampling strategies such as trawling, where the sampling gear sweeps over areas of the seafloor that are larger than important scales of variation in habitat structure. By determining the relationship between the abundance of juvenile snapper and the small-scale elements of habitat structure, we can identify the need for future work to elucidate mechanisms as well as providing information to resource managers on the importance of habitat diversity for juvenile life stages of exploited populations.

\section{MATERIALS AND METHODS}

Study site. The study was conducted in the vicinity of Kawau Bay $\left(36^{\circ} 24^{\prime} \mathrm{S}, 174^{\circ} 48^{\prime} \mathrm{E}\right)$, a large, 10 to $20 \mathrm{~m}$ deep, embayment on the NE coast of the North Island of New Zealand (Fig. 1). Kawau Bay is comprised mainly of soft-sediment habitats that vary both in sediment characteristics and biogenic structure. Five sites were chosen to reflect this habitat variation and to encompass a range of geographic locations around the bay (Fig. 1, Table 1). Kawau Bay was chosen for this study as it enabled us to sample a variety of sedimentary habitats in close proximity, contained reasonable numbers of juvenile snapper and was the site of previous work (Francis 1993, 1994, 1995, Francis \& Williams 1995). Comparative sampling in the Mercury Bay area $\left(36^{\circ} 37^{\prime} \mathrm{S}, 175^{\circ} 47^{\prime} \mathrm{E}\right)$ was discontinued because of very low juvenile snapper abundance. While there has been extensive trawling and dredging in this region, data collected for management of the fishery generally indicate that the density of juvenile snapper is often much lower than at Kawau Bay (Langley 1993).

Sampling. Trapping, long lining or direct observations are the most appropriate methods of estimating fish abundance in relation to habitat features that vary on scales of 10 s to 100 s of metres. We used opera house traps and deployment procedures following the recommendations of Ferrell et al. (1994), who found these traps to be more effective than 3 other types of traps or long-lines. They found consistent catches could be achieved with soak times as low as 20 to $50 \mathrm{~min}$, and were not able to detect a significant effect of time of day on catch rate. We supplemented this information with preliminary trials using different types of bait, soak times and diver and video observations of fish 


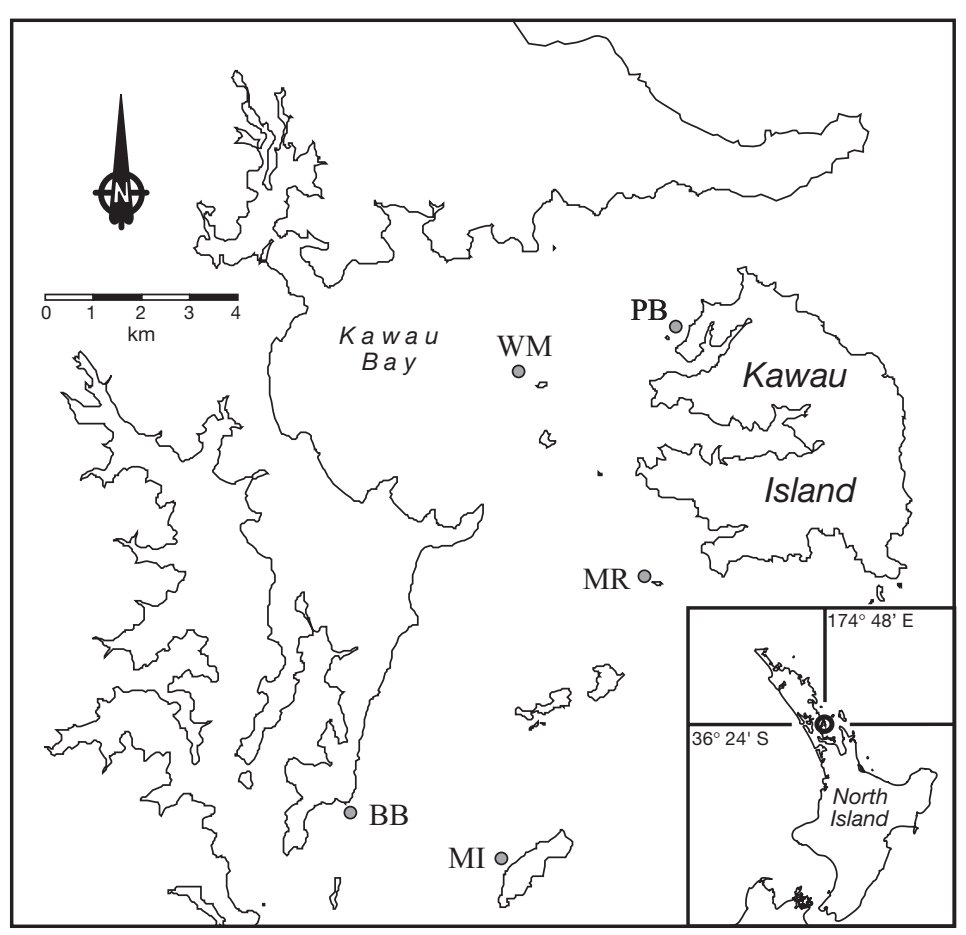

Fig. 1. Map of Kawau Bay, New Zealand, showing the location of the 5 sampling sites. Abbreviations explained in Table 1

juvenile snapper caught in all 5 traps was used in the subsequent statistical modelling. Soak times were similar across sites on each sampling occasion (1-way ANOVA: $F=0.40$, $\mathrm{df}=4, \mathrm{p}=0.8046)$, but varied between occasions (85 to $172 \mathrm{~min}$ ) due to sea conditions and logistic problems. Samples were collected over the summer months of 1998/99 and 1999/2000. Sampling times when very low numbers of fish were caught (i.e. mean of $<1$ snapper at $>2$ of the 5 sites) were not used in the subsequent analysis. In total, 7 sampling occasions were used to relate juvenile snapper abundance to habitat structure (November and December 1998, January, February [2 dates] and April 1999, and February 2000).

Habitat structure. Seafloor habitat structure was quantified at 2 different spatial scales for each of the 5 sites. At the large scale, we used the acoustic technique QTC VIEW $^{\text {TM }}$ to provide a broad overview of the diversity of habitat structure. Potentially simple, single beam acoustic techniques, like QTC, enable habitats to be mapped cheaply and over broader spatial scales than achievable using traditional core or grab

behaviour in and around the opera house traps, as well as deploying the traps at a variety of sites. Traps used were $1.2 \mathrm{~m}$ long, $0.8 \mathrm{~m}$ wide and $0.6 \mathrm{~m}$ high. The traps were covered with red netting of $1 \mathrm{~cm}^{2}$ mesh. The traps had entrances on either short side consisting of $0.25 \mathrm{~m}$ long tunnels that tapered in diameter from 40 to $14 \mathrm{~cm}$. Each trap was baited with 2 dead pilchards Sardinops neopilchardus. The bait was held in a purse of plastic netting, making it impossible for the first fish to enter the trap to swallow the bait. At each site, 5 individual traps were lowered to the seabed, encompassing an area of about 100 to $200 \mathrm{~m}^{2}$ and the total number of sampling techniques. Hamilton et al. (1999) compared this technique with another single beam acoustic technique (RoxAnn) and found QTC to be more consistent and reliable. Between February and March 1999, a $1 \times$ $1 \mathrm{~km}$ square area was mapped at each site using a Simrad EA501P hydrographic sounder and QTC VIEW TM (Series 4) operating at $200 \mathrm{kHz}$ with a ping-rate of $5 \mathrm{~s}^{-1}$, to receive and decompose the sonar signal into 166 variables. All navigation was done using the software package HYDRO ${ }^{\mathrm{TM}}$ and a Trimble DSM212 dGPS, ensuring high spatial positioning accuracy $( \pm 5 \mathrm{~m})$. The square area was mapped by pairs (50 m apart) of $1 \mathrm{~km}$

Table 1. Site description, including sediment type and habitat. Shannon-Wiener diversity ( $\left.\mathrm{H}^{\prime}\right)$ is derived for acoustic habitat elements sampled by QTC View in $1 \times 1 \mathrm{~km}$ blocks. Small-scale habitat elements (number of elements) were counted on 4 transects per site. PB: Pembles; MR: Marteello Rock; WM: West Mayne; BB: Big Bay; MI: Moturoa Island

\begin{tabular}{|c|c|c|c|c|}
\hline Site & Sediment type & Habitat description & $\mathrm{H}^{\prime}$ & No. of elements \\
\hline $\mathrm{PB}$ & $\begin{array}{l}\text { Sand; patches of muddy } \\
\text { sand; shell hash }\end{array}$ & $\begin{array}{l}\text { Scallops, sponges, Atrina zelandica, chaetoperid } \\
\text { tubes, spionid tube mats, burrows and mounds }\end{array}$ & 1.62 & 3.9 \\
\hline MR & $\begin{array}{l}\text { Sand; patches of muddy } \\
\text { sand; pebbles; shell hash }\end{array}$ & Scallops, spionid tube mats, burrows, mounds & 1.55 & 3.8 \\
\hline WM & Sand & $\begin{array}{l}\text { Atrina zelandica, spionid tube mats, } \\
\text { burrows, mounds and gastropod shells }\end{array}$ & 1.24 & 4.3 \\
\hline $\mathrm{BB}$ & $\begin{array}{l}\text { Sand; shell hash; patches } \\
\text { of muddy sand }\end{array}$ & $\begin{array}{l}\text { Atrina zelandica, sponges, } \\
\text { seaweed, spionid tube mats, burrows }\end{array}$ & 1.92 & 3.3 \\
\hline MI & Sand; few patches of shell hash & Atrina zelandica, chaetoperid tubes, holes & 1.61 & 2.8 \\
\hline
\end{tabular}


Table 2. Elements of habitat structure observed by video sampling

\begin{tabular}{|lcl|}
\hline $\begin{array}{l}\text { Immobile } \\
\text { biological features }\end{array}$ & $\begin{array}{c}\text { Sediment grain } \\
\text { size characteristics }\end{array}$ & Miscellaneous \\
\hline Ascidians & $\begin{array}{c}\text { Boulder } \\
(256-4096 \mathrm{~mm}) \\
\text { Coralline algae }\end{array}$ & Sand ripples \\
Chaetopterid tubes & Gravel $(2-4 \mathrm{~mm})$ & Ray pits \\
$\begin{array}{l}\text { Atrina zelandica } \\
\text { Holes and burrows }\end{array}$ & Sand & Shells \\
Hydroids & Sandy mud & Atrina zelandica \\
& Mudrina zelandica \\
Mounds & Mund & Atrina zelandica \\
Scallops Pecten novae- & & upright and dead \\
zelandiae & & Scallop shells \\
Sponges & & Dead sponge \\
Seaweed & & \\
Spionid worm tube mat & & \\
\hline
\end{tabular}

Wiener index: $\mathrm{H}^{\prime}=-\sum_{i} p_{i}\left(\log _{2} p_{i}\right)$, where $p$ represents the frequency distribution of habitat $i$.

To assess small-scale habitat complexity, 2 locations were haphazardly chosen within each site. At each location, two $20 \mathrm{~m}$ transects were laid on the seafloor at right angles to each other. One transect in each pair was always aligned with the tidal flow (typically north-south). Each transect was videotaped using a digital video camera with the lens held perpendicular $0.7 \mathrm{~m}$ above the seabed. For visual classification, the transects were frame grabbed. Quadrats of $30 \times 100 \mathrm{~cm}$ were selected from the grabbed strip, and depending on the number of habitat features observed along each transect, a maximum of five $30 \times 100 \mathrm{~cm}$ quadrats were selected. On transects exhibiting no apparent change in habitat structure, quadrats were positioned at the start and end of the transect. For each quadrat, the number of different habitat features observed (see Table 2) was counted. Means were calculated from these values to produce a single estimate of small-scale habitat structure for each site (see Table 1).

Generalised linear modelling procedures (McCullagh \& Nelder 1989, Crawley 1993) were used to relate the abundance and size of juvenile snapper to habitat structure and a number of other environmental/sampling variables (Table 3). Initially a model with normal error structure and no data transformations was run for each set of explanatory variables. Model fit was evaluated by visual inspection of half normal plots of residuals, together with plots of residuals vs predicted values. It proved unnecessary to transform the data or use other error structures. To develop regression models,

Table 3. Environmental variables and generalised linear models developed to explore patterns in the abundance of juvenile snapper Pagrus auratus. Variables in italics are categorical. Listing 'habitat structure' indicates the inclusion of both large- and small-scale variables. For details on model numbers, refer to text. CPUE: catch per unit effort

\begin{tabular}{|c|c|c|c|c|}
\hline Model & $\begin{array}{l}\text { Independent } \\
\text { variables }\end{array}$ & $\begin{array}{l}\text { Dependent } \\
\text { variables }\end{array}$ & $\begin{array}{l}\text { Interaction with } \\
\text { Date included }\end{array}$ & $\begin{array}{l}\text { 2nd degree polynomial } \\
\text { function included }\end{array}$ \\
\hline 1 & Size & Site, Date & No & No \\
\hline 2 & Abundance & Site, Date & No & No \\
\hline 3 & Abundance & $\begin{array}{l}\text { Time to nearest high tide, Tidal state, } \\
\text { Direction and height, Soak time, Date }\end{array}$ & Yes & $\begin{array}{c}\text { Yes for all } \\
\text { continuous variables }\end{array}$ \\
\hline 4 & CPUE & $\begin{array}{l}\text { Soak time, Date } \\
\text { Habitat structure }\end{array}$ & Yes & $\begin{array}{l}\text { Yes for all } \\
\text { continuous variables }\end{array}$ \\
\hline 5 & Abundance & $\begin{array}{l}\text { Soak time, Date, } \\
\text { Habitat structure }\end{array}$ & Yes & $\begin{array}{c}\text { Yes for all } \\
\text { continuous variables }\end{array}$ \\
\hline 6 & Abundance & $\begin{array}{l}\text { Habitat structure, Potential food, } \\
\text { Soak time, Date }\end{array}$ & Yes & $\begin{array}{l}\text { Yes for all } \\
\text { continuous variables }\end{array}$ \\
\hline
\end{tabular}


we used backwards variable selection with an exit level of $p=0.15$. Even then, variables were dropped from the model only if their removal did not markedly affect the error sum of squares. After finding the most parsimonious model, a number of different orders of dropping variables were tested to make sure that the model produced was the best and most consistent.

\section{RESULTS}

The opera house traps sampled snapper between 40 and $315 \mathrm{~mm}$ fork length (mean \pm 1 SD: $172.4 \pm$ $43.3 \mathrm{~mm}$ ), with no indication of changes in the size of fish caught with respect to site $(\mathrm{p}=0.4187$; Model 1 , Table 3). Other species were rarely collected from the opera house traps (in total, 11 juvenile trevally Caranax geogians, 3 juvenile sweep Scorpis lineotatus, 10 juvenile goatfish Upeneichthys lineatus and 1 unidentified blennie); no decapods or cephalopods were collected. The low and sporadic occurrence of these fish was not considered to influence the numbers of snapper collected in the traps. However, changes in size with date were apparent $(p=0.0193)$, probably indicating growth over the summer. Over all times there were no significant differences in fish abundance between sites ( $p=0.1335$; Model 2, Table 3 ), due predominantly to high variability over time (Fig. 2). Sites MI and WM showed the most variability over time, while Site PB was the most consistent in fish abundance.

Initial modelling concentrated on determining whether changes in abundance over time and site could be explained by differences in tidal state and soak time (Model 3, Table 3). This model provided no evidence $(p>0.15)$ that the tide was an important

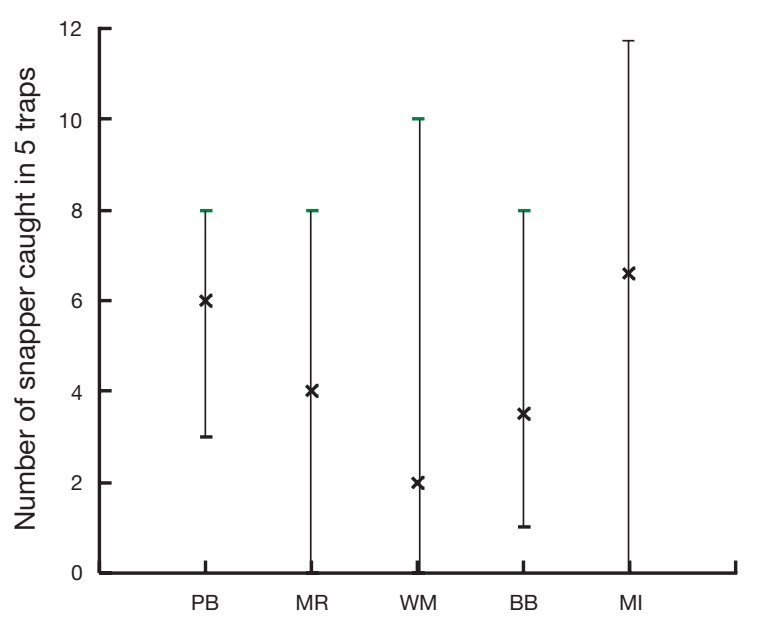

Fig. 2. Pagrus auratus. Median and interquartile range for the abundance of juvenile snapper found over time at each of the 5 sites. See Table 1 for definition of abbreviations influence on the abundance of juvenile snapper. However, there was an indication that soak time might play a role $(p=0.15)$ and we were concerned with the potential for fish to behave differently towards cages in habitats with different levels of structure. Thus, in developing a generalised linear model to identify any relationship between habitat structure and the abundance of juvenile snapper, we maintained soak time in the model.

Initially this was done by normalising abundance by soak time (i.e. catch per unit effort [CPUE], Model 4, Table 3). However, there is the potential for interactions between soak time and habitat structure, so another model (Model 5, Table 3) was constructed that included continuous variables of habitat structure and soak time as 2nd-degree polynomial functions to account for potential non-monotonic responses. While both models resulted in significant positive relationships between fish caught and habitat structure, the model with normalised abundance had a lower adjusted $\mathrm{R}^{2}$ (10\% less).

Lastly, a model (Model 6, Table 3) was investigated that included the density of potential food (macrofaunal densities calculated from Thrush et al. 2001), as well as habitat structure. However, the importance of macrofaunal density was lower than habitat structure and was always dropped from the model.

The final model accounted for $74 \%$ of the variability in the abundance of juvenile snapper (Table 4), with a significant and positive influence of the variety and number of habitat structure elements, at both the small and large scale, on the abundance of juvenile snapper. No significant date interaction terms were found. Soak time was important, although this was not a simple monotonic relationship. Instead a complex interplay between increasing number of fish caught and increasing soak time, and a negative relationship between soak time and the habitat structure, measured at both the large and the small scale, was indicated.

\section{DISCUSSION}

Our results extend the natural history information available for the juvenile life-stage of a commercially important species. The interquartile size range for the juvenile snapper captured by the opera house traps was 136 to $200 \mathrm{~mm}$ fork length. The size for age characteristics described by Francis \& Williams (1995), based on estimating age from otoliths (Francis 1994), indicates that the fish we sampled were a mixed assemblage of Year 1+ and 2+ fish. The effectiveness of the opera house traps in catching juvenile snapper was similar to that reported by Ferrell et al. (1994), with an overall mean of about 1 fish per trap. Our results 
Table 4. Generalised linear model relating the abundance of juvenile snapper Pagrus auratus to habitat structure in Kawau Bay. $\mathrm{R}^{2}=0.74$

\begin{tabular}{|lrrrrr|}
\hline & df & SS & $F$ & p & Parameter estimates \\
\hline Date & 7 & 635.1 & 2.21 & 0.0743 & 3.44 \\
Soak time & 1 & 374.5 & 9.09 & 0.0064 & 52.91 \\
Small-scale habitat structure & 1 & 210.8 & 5.12 & 0.0339 & 114.2 \\
Large-scale habitat structure & 1 & 277.8 & 6.74 & 0.0165 & -0.4595 \\
Soak time $\times$ Small-scale habitat structure & 1 & 287.3 & 6.97 & 0.0149 & -0.9754 \\
Soak time $\times$ Large-scale habitat structure & 1 & 365.9 & 8.88 & 0.0069 & \\
Model & 12 & 2626.4 & 5.31 & 0.0004 & \\
Error & 22 & 906.6 & & & \\
\hline
\end{tabular}

emphasise the importance of habitat structure in influencing the abundance of juvenile snapper. This result contrasts with Kingett \& Choat (1981) who did not find a relationship between the abundance of Year 0+ snapper and topographic structure, although it is not clear how the authors quantified this variable. Our results refine the conclusions of Francis (1995), due to the finer scale sampling possible with traps rather than trawls, and the quantitative description of fine-scale habitat structure. Francis (1995) concluded that variation in the abundance of juvenile snapper in Kawau Bay result from higher juvenile snapper abundances associated with muddy sediments. Our analysis indicates that it is the habitat features nested within the broad-scale 'sand vs mud' type habitat classification that is important in influencing the abundance of juvenile snapper. This implies that seafloor habitats will need to be mapped at finer scales of resolution than simple measures of sediment type if maps are to be useful in defining and managing fish habitat.

We found no indication that the time of day or time of tide influenced the number of juvenile snapper caught. However, the role of soak time was more interesting: in combination with other sampling variables it only had a very weak influence, but in combination with habitat structure it became very important. This suggests that the effect of soak time on the abundance of juvenile snapper varies with habitat structure. Previous studies have demonstrated that trap and pot efficiency will vary with various factors including habitat (Blaustein 1989, Rozas \& Minello 1997, Kneib \& Craig 2001). Soak time involves the interaction of a number of factors, including changes in the influence of the bait-odour plume in attracting fish, rates of entry and exit of fish within the cage, and density of fish within the cage, which will influence the number of fish in the trap when it is pulled from the seabed. The identification of non-linear responses and interactions between soak time and habitat structure may well reflect behavioural responses of the fish to the cage structure, responses which are influenced by the surrounding habitat. Robichaud et al. (2000) reports that Antillean fish traps were less effective at capturing fish adjacent to coral reef habitats in comparison to less structured habitats, even though fish densities were higher in the vicinity of the coral reef. In habitats with higher degrees of structure that provide refugia, fish may be less attracted to the cage structure than in more simple habitats. The negative interaction between soak time and both scales of habitat structure on juvenile snapper abundance in our model support the findings of Robichaud et al. (2000). Although research is needed on the behaviour of snapper, the implication of our statistical models is that such relationships between capture efficiency of trap and habitat would tend to weaken the strength of relationships between abundance and habitat structure.

Two mechanisms are commonly invoked to explain relationships between fish abundance and habitat structure: either the provision of refugia from predation or the provision of food. Gut analysis of some of the juvenile snapper caught in this study indicates they are eating a wide variety of macrofauna (authors' unpubl. data). We found no evidence for a relationship between potential food and the abundance of juvenile snapper when using macrofauna density estimates derived from Thrush et al. (2001). The spatial scale of sampling for macrofauna within sites integrates over small spatial heterogeneities such as ray pits that might include small accumulations of organic material. More general observations of the seafloor by divers and underwater video did not reveal any specific production hot spots that might be expected to increase fish numbers (Jenkins et al. 1993, Vetter \& Dayton 1999). Thus, our work suggests that habitat structures providing refugia are important. The early life history (egg to larval stages) makes most exploited fish populations highly dynamic (see Francis 1993 and Zeldis 1993 for snapper). However, in theory at least one demographic rate must be density dependent, at some stage or location, to ensure population regulation (Hixon \& Carr 1997). Predation is commonly considered as the mechanism inducing density-dependent mortality in juveniles of exploited fish populations (e.g. 
Sissenwine 1984). Modifying the risk of predation for an individual involves searching out areas that reduce a predator's ability to locate and capture prey (Giske et al. 1998). A number of studies have demonstrated that survivorship of juvenile Atlantic cod Gadus morhua is related to habitat structure, which may at least partly explain the slow recovery of the stock after its collapse (Lough et al. 1989, Gotceitas \& Brown 1993, Tupper \& Boutilier 1995, Gregory \& Anderson 1997, Lindholm et al. 1999). This implies that we need to understand the behaviour and ecology of fish over various space and time scales, as well as their recruitment dynamics, to sustainably manage populations (Bailey 1994).

Our work provides the first empirical evidence that small-scale habitat structure within soft-sediment habitats influences the abundance of juvenile snapper. The sites sampled in Kawau Bay spanned a range of habitats that differed both in sediment characteristics and the presence of a variety of epifauna. They do not reflect what is typically considered to be a highly structured seafloor habitat such as patch reefs. The variety of relatively low-density features observed create small-scale structures on the seafloor, typical of what could be expected over large expanses of coastal and shelf soft-sediment environments. These features can have an important and positive influence on macrobenthic diversity (Thrush et al. 2001), indicating the potential for positive interactions between maintaining both juvenile fish abundance and biodiversity. When the seafloor is disturbed by trawling or dredging, biogenic elements of habitat structure are usually removed, although the magnitude of effects will depend on the extent, frequency and intensity of disturbance. However, the sensitivity and resilience of resident species that contribute to habitat structure are also important (Thrush \& Dayton 2002). Given the growth rate and dispersal of many of these organisms, recovery is likely to be sufficiently slow to result in long-term changes in fished areas (Dayton et al. 1995, Jennings \& Kaiser 1998, Thrush et al. 1998, Auster \& Langton 1999).

Our results highlight the potential links between fisheries and habitats, and the consequences of declines in habitat structure in soft-sediment environments that can occur as a result of anthropogenic disturbances such as trawling and dredging. In this paper we have identified a positive relationship between habitat structure and the abundance of juvenile snapper across a wide array of the soft-sediment habitats of Kawau Bay. Further research is needed to assess the generality of this relationship to encompass the spatial extent of the fishery, and most importantly to understand the mechanisms that generate this pattern and its influence on the population dynamics of this valuable fishery. The analysis of habitat does demonstrate that simplistic broad-scale classifications of seafloor habitats may be insufficient to describe the variability in abundance of juvenile demersal fish. Although gathering natural history and ecological information on exploited stocks to identify and assess the benefits of improved juvenile survivorship is difficult in coastal and shelf environments, evidence is growing of the links between habitat quality and fish stocks, at least for some species (Sainsbury 1988, Steves et al. 1999, Turner et al. 1999, Kaiser et al. 2000). This type of research is necessary if science is to support the policy initiatives in fisheries management that seek to identify and sustainably manage habitats of importance to exploited populations, while maintaining marine biodiversity.

Acknowledgements. This research was supported by FRST CO1X0007. We thank Mark Morrison and Martin Cryer for their assistance in developing the fish sampling techniques. Malcolm Francis, Martin Cryer, Carolyn Lundquist and Vonda Cummings commented on earlier versions of the manuscript. Rod Budd and Jim Drury collected the QTC data and Pierre Legendre provided the analysis techniques for the measure of large-scale habitat structure. We also thank Ron Kneib for an e-discussion on soak time and for providing preprints of his work. Comments from 4 anonymous reviewers were also appreciated.

\section{LITERATURE CITED}

Able KW, Manderson JP, Studholme AL (1999) Habitat quality for shallow water fishes in an urban estuary: the effects of man-made structures on growth. Mar Ecol Prog Ser 187: $227-235$

Addicot JF, Aho JM, Antolin MF, Padilla DK, Richardson JS, Soluk DA (1987) Ecological neighbourhoods: scaling environmental patterns. Oikos 49:340-346

Auster PJ, Langton RW (1999) The effects of fishing on fish habitat. Am Fish Soc Symp 22:150-187

Auster PJ, Malatesta RJ, LaRosa SC (1995) Patterns of microhabitat utilization by mobile megafauna on the southern New England (USA) continental shelf and slope. Mar Ecol Prog Ser 127:77-85

Bailey KM (1994) Predation on juvenile flatfish and recruitment variability. Neth J Sea Res 32:175-189

Blaustein L (1989) Effects of various factors on the efficiency of minnow traps to sample mosquitofish (Gambusai affinis) and green sunfish (Lepomis cyanellus) populations. J Am Mosq Control Assoc 5:29-35

Bradstock M, Gordon DP (1983) Coral-like bryozoan growths in Tasman Bay, and their protection to conserve commercial fish stocks. NZ J Mar Freshw Res 17:159-163

Crawley MJ (1993) GLIM for ecologists. Blackwell, Oxford

Dayton PK, Thrush SF, Agardy TM, Hofman RJ (1995) Environmental effects of fishing. Aquat Conserv 5:205-232

Ferrell D, Avery R, Blount C, Hayes L, Pratt R (1994) The utility of small, baited traps for surveys of snapper (Pagrus auratus) and other demersal fishes. NSW Fisheries Research Institute, Cronulla

Fluharty D (2000) Habitat protection, ecological issues, and implementation of the Sustainable Fisheries Act. Ecol Appl 10:325-337 
Francis MP (1993) Does water temperature determine year class strength in New Zealand snapper (Pagrus auratus, Sparidae). Fish Oceanogr 2:65-72

Francis MP (1994) Growth of juvenile snapper, Pagrus auratus. NZ J Mar Freshw Res 28:201-218

Francis MP (1995) Spatial and seasonal variation in the abundance of juvenile snapper (Pagrus auratus) in the northwestern Hauraki Gulf. NZ J Mar Freshw Res 29: 565-579

Francis MP, Williams MW (1995) Diel variation in trawl catch rates of Pagrus auratus (Sparidae). Fish Res 24:301-310

Giske J, Huse G, Fiksen O (1998) Modelling spatial dynamics of fish. Rev Fish Biol Fish 8:57-91

Gotceitas V, Brown JA (1993) Substrate selection by juvenile Atlantic cod (Gadus morhua): effects of predation risk. Oecologia 93:346-351

Gregory RS, Anderson JT (1997) Substrate selection and use of protective cover by juvenile Atlantic cod (Gadus morhua) in inshore waters of Newfoundland. Mar Ecol Prog Ser 146:9-20

Hamilton LJ, Mulhearn PJ, Poeckert R (1999) Comparison of RoxAnn and QTC-View acoustic bottom classification system performance for the Cairns area, Great Barrier Reef, Australia. Cont Shelf Res 19:1577-1597

Heck KLJ, Thoman TA (1981) Experiments on predator-prey interactions in vegetated aquatic habitats. J Exp Mar Biol Ecol 53:125-134

Hixon MA, Carr MH (1997) Synergistic predation, density dependence, and population regulation in marine fish. Science 277:946-949

Jenkins GP, Shaw MR, Stewart BD (1993) Spatial variation in food-limited growth of juvenile greenback flounder, Rhombosolea tapirina: evidence from otolith daily increments and otolith scaling. Can J Fish Aquat Sci 50: 2558-2567

Jennings S, Kaiser MJ (1998) The effects of fishing on marine ecosystems. Adv Mar Biol 34:203-314

Kaiser MJ, Spence FE, Hart PJB (2000) Fishing-gear restrictions and conservation of benthic habitat complexity. Conserv Biol 14:1512-1525

Kingett PD, Choat JH (1981) Analysis of density and distribution patterns in Chrysophrys auratus (Pisces: Sparidae) within a reef environment: an experimental approach. Mar Ecol Prog Ser 5:283-290

Kneib RT, Craig AH (2001) Efficacy of minnow traps for sampling mummichogs in tidal marshes. Estuaries 24:884-893

Kotliar NB, Wiens JA (1990) Multiple scales of patchiness and patch structure: a hierarchical framework for the study of heterogeneity. Oikos 59:253-260

Langley A (1993) The distribution of juvenile snapper within the Auckland Fishery Management Area. Northern Fisheries Region Internal Report No. 113

Legendre P, Ellingsen KE, Bjornborn E, Casgrain P (2002) Acoustic seabed classification methodology: improved statistical method. Can J Fish Aquat Sci 59:1085-1089

Lindholm JB, Auster PJ, Kaufman LS (1999) Habitat-mediated survivorship of juvenile (0-year) Atlantic cod Gadus morhua. Mar Ecol Prog Ser 180:247-255

Lough RG, Valentine PC, Potter DC, Auditore PJ, Bolz GR,

Editorial responsibility: Otto Kinne (Editor),

Oldendorf/Luhe, Germany
Neilson JD, Perry RI (1989) Ecology and distribution of juvenile cod and haddock in relation to sediment type and the bottom currents in eastern Georges Bank. Mar Ecol Prog Ser 56:1-12

McCullagh P, Nelder JA (1989) Generalised linear models. Chapman \& Hall, London

Persson L, Eklov P (1995) Prey refuges affecting interactions between piscivorous perch and juvenile perch and roach. Ecology 76:70-81

Robichaud D, Hunte W, Chapman MR (2000) Factors affecting the catchability of reef fishes in Antillean fish traps. Bull Mar Sci 67:831-844

Rooker JR, Holt GJ, Holt SA (1998) Vulnerability of newly settled red drum (Scianops ocellatus) to predatory fish: is early-life survival enhanced by seagrass meadows? Mar Biol 131:145-151

Rozas LP, Minello TJ (1997) Estimating densities of small fishes and decapod crustaceans in shallow estuarine habitats: a review of sampling design with a focus on gear selection. Estuaries 20:199-213

Sainsbury KJ (1988) The ecological basis of multispecies fisheries and management of a demersal fishery in tropical Australia. In: Gulland JA (ed) Fish population dynamics: the implications for management. Wiley, New York, p 349-382

Schneider DC, Gagnon JM, Gilkinson KD (1987) Patchiness of epibenthic megafauna on the outer Grand Banks of Newfoundland. Mar Ecol Prog Ser 39:1-13

Sissenwine MP (1984) Why do fish populations vary? In: May RM (ed) Exploitation of marine communities. SpringerVerlag, Berlin, p 59-94

Steves BP, Cowen RK, Malchoff MH (1999) Settlement and nursery habitats for demersal fishes on the continental shelf of the New York Bight. Fish Bull 98:167-188

Thrush SF, Dayton PK (2002) Disturbance to marine benthic habitats by trawling and dredging-implications for marine biodiversity. Annu Rev Ecol Syst 33:449-473

Thrush SF, Hewitt JE, Cummings VJ, Dayton PK and 6 others (1998) Disturbance of the marine benthic habitat by commercial fishing: impacts at the scale of the fishery. Ecol Appl 8:866-879

Thrush SF, Hewitt JE, Funnell GA, Cummings VJ, Ellis J, Schultz D, Talley D, Norkko A (2001) Fishing disturbance and marine biodiversity: the role of habitat structure in simple soft-sediment systems. Mar Ecol Prog Ser 221: 255-264

Tupper M, Boutilier RG (1995) Effects of habitat on settlement, growth and postsettlement survival of Atlantic cod (Gadus morhua). Can J Fish Aquat Sci 52:1834-1841

Turner SJ, Thrush SF, Hewitt JE, Cummings VJ, Funnell G (1999) Fishing impacts and the degradation or loss of habitat structure. Fish Manage Ecol 6:401-420

Vetter EW, Dayton PK (1999) Organic enrichment by macrophyte detritus, and abundance patterns of megafaunal populations in submarine canyons. Mar Ecol Prog Ser 186: $137-148$

Zeldis JR (1993) Applicability of egg surveys for spawningstock biomass estimation of snapper, orange roughy and hoki in New Zealand. Bull Mar Sci 53:864-890

Submitted: April 5, 2002; Accepted: October 9, 2002

Proofs received from author(s): December 2, 2002 